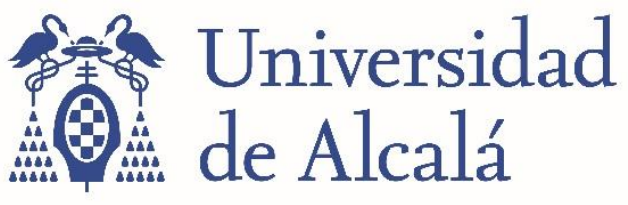

BIBLIOTECA

Document downloaded from the institutional repository of the University of Alcala: http://dspace.uah.es/dspace/

This is a preprint version of the following published document:

Usola, M., Villar-Salvador, P., Oliet, J. \& Warren, C.R. 2014, " Foliar absorption and root translocation of nitrogen from different chemical forms in seedlings of two Mediterranean trees ", Environmental and Experimental Botany, vol. 104, pp. 34-43.

Available at https://doi.org/10.1016/j.envexpbot.2014.03.004

(C) 2017 American Mathematical Society
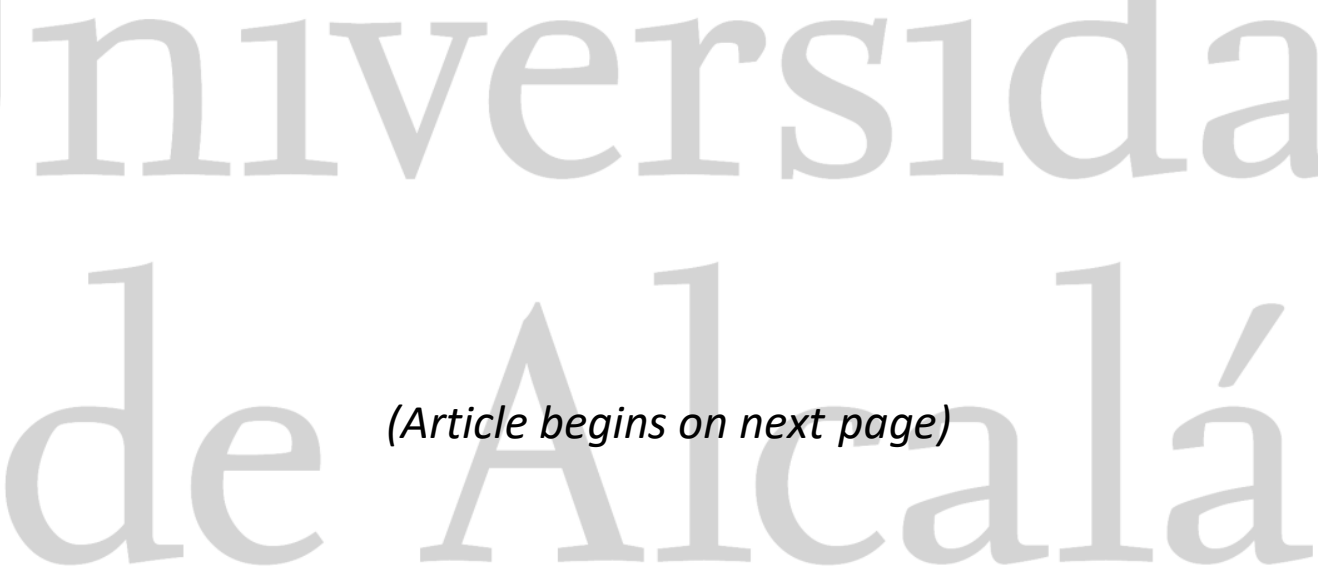

(Article begins on next page)

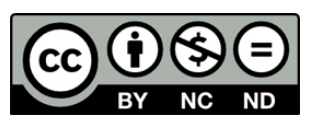

This work is licensed under a

Creative Commons Attribution-NonCommercial-NoDerivatives

4.0 International License. 


\title{
Foliar absorption and root translocation of nitrogen from different chemical forms in seedlings of two Mediterranean trees
}

\author{
Mercedes Uscola, Pedro Villar-Salvador, Juan Oliet, Charles R. Warren
}

\section{Highlights}

I Quercus ilex had higher $\mathrm{N}$ foliar absorption than $P$. hapelensis.

2 In both species, rates of foliar $\mathrm{N}$ absorption rates were: urea $>\mathrm{NH}_{4}{ }^{+} \geq$glycine $\geq \mathrm{NO}_{3}$.

3 Cuticular conductance only explained intraspecific but not interspecific differences in $\mathrm{N}$ absorption rates.

4 Absorbed $\mathrm{N}$ was rapidly translocated to roots, especially from organic $\mathrm{N}$ sources.

5 Foliar fertilization increased plant $\mathrm{N}$ content by stimulating root uptake. 


\title{
Foliar absorption and root translocation of nitrogen from different chemical forms in seedlings of two Mediterranean trees
}

\author{
Mercedes Uscola ${ }^{1,2 *}$, Pedro Villar-Salvador ${ }^{1}$, Juan Oliet $^{3}$, Charles R. Warren ${ }^{4}$ \\ ${ }^{1}$ Forest Ecology and Restoration Group, Departamento de Ciencias de la Vida, U.D. \\ Ecología, Universidad de Alcalá, Campus Universitario, A.P. 20, E-28805, Alcalá de \\ Henares, Madrid, Spain. (pedro.villar@uah.es).
}

${ }^{2}$ Current address: Department of Forestry and Natural Reforms, Pfendler hall of Agriculture, 126, Purdue University, West Lafayette, IN 47907-2061, USA (muscolaf@purdue.edu)

*Author for correspondence [email: muscolaf@purdue.edu]

${ }^{3}$ Departamento de Silvopascicultura, Escuela Técnica Superior de Ingeniería de Montes,

Forestal y del Medio Natural, Universidad Politécnica de Madrid, E-28040 Madrid, is Spain (juan.oliet@upm.es)

${ }^{4}$ School of Biological Sciences, Heydon-Laurence Building A08, The University of Sydney, 2006, Sydney, New South Wales, Australia, (charles.warren@sydney.edu.au)

\begin{abstract}
Abbreviations: Cuticular conductance $\left(g_{\mathrm{c}}\right)$; absorbing surface (AS); $\mathrm{N}$ absorption efficiency $\left(N_{\text {recovery }}\right) ; \mathrm{N}$ absorbed from a labeled $\mathrm{N}$ form $\left(\mathrm{N}_{\text {absorbed }}\right) ; \mathrm{C}$ absorbed from a labeled $\mathrm{N}$ form ( $\left.\mathrm{C}_{\text {absorbed }}\right)$
\end{abstract}




\section{Abstract}

Along with root uptake, plants can also absorb $\mathrm{N}$ through leaves. There are few comparative studies on the foliar absorption of $\mathrm{N}$ from different chemical forms of $\mathrm{N}$ in forest tree species. We compared the foliar $\mathrm{N}$ absorption capacity in seedlings of two forest trees widespread in the Mediterranean, Quercus ilex and Pinus halepensis. Plants were sprayed with the following individual $\mathrm{N}$ forms at $40 \mathrm{mM} \mathrm{N}:{ }^{15} \mathrm{~N}$-nitrate $\left(\mathrm{NO}_{3}{ }^{-}\right),{ }^{15} \mathrm{~N}$-ammonium $\left(\mathrm{NH}_{4}{ }^{+}\right),{ }^{15} \mathrm{~N}$-urea or ${ }^{13} \mathrm{C}$ and ${ }^{15} \mathrm{~N}$ dual-labeled glycine. Cuticular conductance was used as a surrogate of cuticle permeability to water. Quercus ilex had higher N foliar absorption than P. hapelensis. Neither cuticular conductance nor shoot surface area explained $\mathrm{N}$ differences in absorption rate between species, which were instead likely linked to differences in stomatal density and presence of trichomes. In both species, foliar $\mathrm{N}$ absorption rate and $\mathrm{N}$ recovery differed among $\mathrm{N}$ forms: urea $>\mathrm{NH}_{4}{ }^{+} \mathrm{Q}$ glycine $\mathrm{CNO}_{3}{ }^{-}$. Differences in $\mathrm{N}$ absorption rate among $\mathrm{N}$ forms were correlated with their physico-chemical properties. The strong positive relationship between ${ }^{15} \mathrm{~N}$ and ${ }^{13} \mathrm{C}$ uptake together with detection in shoots of intact dual-labeled glycine (measured by gas chromatography-mass spectrometry), indicated that a significant fraction of glycine was absorbed intact by the seedlings. In both species, higher cuticular conductance was related to faster $\mathrm{N}$ absorption from all forms except $\mathrm{NO}_{3}{ }^{-}$. Cuticular conductance had a stronger effect on $\mathrm{N}$ absorption from urea and $\mathrm{NH}_{4}{ }^{+}$than $\mathrm{N}$ absorption from glycine, and the effects were more intense in $Q$. ilex than in P. halepensis. This suggests that variations in cuticle permeability in both species are determined by different mechanisms and that each $\mathrm{N}$ form was differently affected. Absorbed $\mathrm{N}$ was rapidly translocated to roots, with a larger proportion of $\mathrm{N}$ from organic forms being translocated than $\mathrm{N}$ from inorganic forms. Foliar fertilization increased plant $\mathrm{N}$ content, especially in urea fertilized plants, but direct foliar absorption only explained up to $10 \%$ of $\mathrm{N}$ content increase. This study demonstrates that two important Mediterranean 
forest tree species can absorb through their leaves both, inorganic and organic $\mathrm{N}$ forms. This has important ecological and applied implications, because all chemical forms of $\mathrm{N}$ are present in natural $\mathrm{N}$ deposition. Also results show that foliar $\mathrm{N}$ fertilization can play an important role for seedling $\mathrm{N}$ nutrition, and that the effect will have different impacts depending on the species.

Key words: ammonium; cuticular conductance; glycine; nitrate; Pinus halepensis; Quercus ilex; urea.

\section{Introduction}

Nitrogen $(\mathrm{N})$ commonly limits productivity in natural and managed terrestrial ecosystems (LeBauer and Treseder, 2008). Nitrogen demand for plant growth can be met either by external sources or by remobilization of internal stores (Millard and Grelet, 2010). One external source is root uptake, while plants can also absorb $\mathrm{N}$ through leaves (Fageria et al., 2009; Burkhardt, 2010) and the foliar pathway can be significant in terms of plant nutrition and function (Rennenberg and Gessler, 1999; Sanz et al., 2002).

Foliar absorption of compounds is assumed to mainly occur via the cuticle (Peuke et al., 1998; Schreiber, 2005). This is because it is partially permeable to gases, water, and several water and oil soluble compounds, in spite of the main role of the plant cuticle being to prevent uncontrolled water loss from plants to the atmosphere (Baur et al., 1997; Santier and Chamel, 1998; Schreiber, 2005). Cuticle thickness and composition varies among species, while within plant species, properties of the cuticle may vary depending on growth conditions (Riederer and Schreiber, 2001). Variation in cuticle thickness and composition may explain differences among plants in the rate at which compounds are absorbed (Baur et al., 1997; Schreiber, 2005; Eichert and Goldbach, 2008). Leaf cuticular conductance $\left(g_{c}\right)$ to water vapor is strongly 
determined by cuticle structure and chemical properties and, consequently, it can be a proxy of cuticle permeability (Niederl et al., 1998; Burghardt and Riederer, 2003; Schreiber, 2005). In addition to absorption via the cuticle, nutrients may also be absorbed through stomata (Schreiber, 2005; Eichert et al., 2008) and trichomes (Benzing et al., 1976).

In natural and crop systems, $\mathrm{N}$ reaches the leaf surface via dry and wet deposition (Rennenberg and Gessler, 1999; Sanz et al., 2002). Although organic N forms such as amino acids and urea make a smaller contribution to $\mathrm{N}$ deposition than inorganic $\mathrm{N}$ forms, they may still represent up to $25 \%$ of total $\mathrm{N}$ deposition (Cornell, 2011). Despite accounting for a substantial fraction of $\mathrm{N}$ deposition, few studies have examined the absorption of organic $\mathrm{N}$ deposition on plants (Cornell, 2011). Moreover, man has dramatically increased $\mathrm{N}$ deposition in southern Europe (Fagerli and Aas, 2008; Cornell, 2011). Most N deposited in semi-arid regions, such as in Mediterranean-climate regions, enters as dry deposition, which is mainly concentrated during the dry season (Raison and Stottlemyer, 1991; Ochoa-Hueso et al., 2011). Rates of inorganic nitrogen deposition in common forest systems in the Mediterranean basin can be substantial with reports of up to $22 \mathrm{~kg} \mathrm{ha}^{-1} \mathrm{yr}^{-1}$ in Quercus ilex L. (holm oak) woodlands (Roda et al., 2002) and $38 \mathrm{~kg} \mathrm{ha}^{-1} \mathrm{yr}^{-1}$ in Pinus halepensis Mill. (Aleppo pine) woodlands (Michopoulos et al., 2004), with canopies retaining up to $70 \%$ of deposited N (Adriaenssens et al., 2010). In the California Mediterranean climate, Bytnerowicz and Fenn (1996) showed that $\mathrm{NO}_{3}^{-}$is deposited on leaves at rates as high as $455 \mu \mathrm{g} \mathrm{m}^{-2} \mathrm{~h}^{-1}$ and accumulates during prolonged dry periods (more than 120 days in some areas (VicenteSerrano, 2006)). A consequence of accumulation during dry spells is that very small rain events $(<0.3$ $\mathrm{mm}$ ) or dew deposition in early autumn can lead to highly concentrated $\mathrm{N}$ solutions on leaf surfaces (Ochoa-Hueso et al., 2011). Thus, we believe that use of high concentrations of different chemical forms of $\mathrm{N}$ in studies on foliar $\mathrm{N}$ uptake can be ecologically realistic 
especially for Mediterranean climates (Burkhardt, 2010; Ochoa-Hueso et al., 2011) and may be useful for disentangling the negative versus positive effects of $\mathrm{N}$ deposition.

Nutrients can also reach the leaf surface in crop systems via foliar fertilization, which is a useful tool to supply nutrients to plants under different circumstances. Also, during high nutrient-demand periods, root uptake and phloem transport cannot meet plant nutrient demands (Dong et al., 2002; Bi and Scagel, 2008; Fernández et al., 2013). Foliar fertilization is a simple, economic and efficient way to supplement nutrients to crops because it allows nutrients to be directly incorporated to metabolism with less microbial competition and nutrient leaching than when fertilizer is applied to the soil (Fageria et al., 2009; Burkhardt, 2010). Unlike crop plants, foliar fertilization is rarely used in forest nurseries and plantations but it has potential for nutrient loading of seedlings without stimulating new growth or delaying dormancy during autumn (Bi and Scagel, 2008). Foliar fertilization can be a strategic solution for improving nutrition of seedlings planted in very poor soils or nutrient limited as per phosphorus and iron occurrence on limestone soils (Zohlen and Tyler, 2000), or under arid conditions (Ruiz Navarro, 2012).

Nitrogen nutrition plays an important role in the field performance of seedlings in forest plantations (Villar-Salvador et al., 2012). Urea, $\mathrm{NH}_{4}{ }^{+}$and $\mathrm{NO}_{3}{ }^{-}$are typical $\mathrm{N}$ forms used for supplying $\mathrm{N}$ via foliar fertilization. Urea is widely used because it has lower toxicity than inorganic $\mathrm{N}$ forms and is highly soluble in both water and oil (Bondada et al., 2006; Stiegler et al., 2009). Most studies on foliar absorption of $\mathrm{N}$ have been made with inorganic forms or urea independently, which complicates comparisons among $\mathrm{N}$ forms (Bowman and Paul, 1992; Dong et al., 2002; Bondada et al., 2006). Although plants have the ability to absorb more complex organic compounds than urea, as amino acids (Baur et al., 1997; Inselsbacher et al., 2007), few studies have compared the foliar absorption of amino acids with other chemical 
forms of N (but see Eberhardt and Pritchett, 1971; Stiegler et al., 2009). Including a variety of chemical forms of $\mathrm{N}$ in studies may be important because previous studies have shown different forms of foliar-applied $\mathrm{N}$ differentially affect plant growth, development and metabolism, plant hormone relations and the uptake of other nutrients (Peuke et al., 1998). For instance, the foliar absorption of $\mathrm{NH}_{4}{ }^{+}$increases phosphorous uptake, while $\mathrm{NO}_{3}{ }^{-}$foliar absorption enhances potassium uptake (Peuke et al., 1998). Similarly, absorption of intact amino acids can decrease plant N metabolic costs, enhancing growth (Maini, 2006). Thus, selecting appropriate chemical forms of $\mathrm{N}$ for foliar sprays is not only important for maximizing absorption efficiency or plant performance but also to minimize potential foliage damage (Fageria et al., 2009; Burkhardt, 2010).

The objective of our study was to compare short term foliar absorption and subsequent translocation to roots of $\mathrm{N}$ in four chemical forms (urea, glycine, $\mathrm{NH}_{4}{ }^{+}$, and $\mathrm{NO}_{3}{ }^{-}$) in two Mediterranean evergreen trees, $P$. halepensis and Q. ilex ssp. ballota (Desf) Samp (thereafter Q. ilex). Moreover, we assessed whether both tree species can take up intact glycine via leaves. Translocation to roots was used as an indicator of the ability to transport $\mathrm{N}$ absorbed by the leaves to other plant organs. The two species have contrasting ecological and morphophysiological characteristics and are widely distributed in the Mediterranean basin and used for afforestation (Zavala et al., 2000). Pinus halepensis is a fast growing pioneer tree (Zavala et al., 2000), which has lower stomatal conductance and density than $Q$. ilex and lacks trichomes (Boddi et al., 2002; Baquedano and Castillo, 2006). By contrast, Q. ilex is a slow growing late-succesional species (Zavala et al., 2000), whose leaves have a dense layer of trichomes on the abaxial surface (Paoletti et al., 1998). We hypothesized that (1) Q. ilex will have higher rates of foliar $\mathrm{N}$ absorption than P. halepensis, due to its higher stomata density and presence of trichomes. (2) Each $\mathrm{N}$ form will have different uptake rates in accordance with 
their physicochemical properties and be higher in urea due to its chemical properties e.g. higher solubility. (3) Proportions of $\mathrm{N}$ translocated to roots will be higher in the $\mathrm{N}$ forms and species with higher uptake rates.

\section{Material and methods}

\subsection{Foliar treatments, experimental design and ${ }^{15} \mathrm{~N}-{ }^{13} \mathrm{C}$ labeling}

Ninety-six seedlings per species were cultivated outdoors at the nursery of the Centro Nacional de Mejora Genética Forestal "El Serranillo" (MAGRAMA) using seeds from inland Iberia Peninsula provenances. Seedlings were grown for 14 months in individual $305 \mathrm{~mL}$ pots (Super-Leach $^{\mathrm{TM}}$, Bardi S.A.L., Navarra, Spain) filled with fertilized peat, N/P/K 14/16/18 + microelements (Kekkilä WHITE 420 F6, Kekkilä Oy, Finland) following standard cultivation protocols in Mediterranean nurseries (Villar-Salvador et al., 2004a). The $\mathrm{N}$ forms tested for foliar $\mathrm{N}$ absorption were: ammonium $\left(\mathrm{NH}_{4}{ }^{+}\right)$, nitrate $\left(\mathrm{NO}_{3}{ }^{-}\right)$, urea $\left(\mathrm{CO}\left(\mathrm{NH}_{2}\right)_{2}\right)$, and glycine $\left(\mathrm{NH}_{2} \mathrm{CH}_{2} \mathrm{COOH}\right)$. All $\mathrm{N}$ forms were supplied at a concentration of $40 \mathrm{mM} \mathrm{N}$. This value is higher than the $2 \mathrm{mM} \mathrm{N}$ commonly used in studies on atmospheric wet deposition of $\mathrm{N}$ (Brumme et al., 1992; Adriaenssens et al., 2010), but only slightly higher than the 20-30 mM $\mathrm{N}$ typically used for foliar fertilization of crop species (Klein and Weinbaum, 1985; Peuke et al., 1998; Fageria et al., 2009). In addition, $40 \mathrm{mM} \mathrm{N}$ improved seedling performance in foliar experiments with Pinus species (Eberhardt and Pritchett, 1971; Montville, 1996).

Glycine and urea were supplied as free forms, $\mathrm{NO}_{3}{ }^{-}$was supplied as $\mathrm{KNO}_{3}$, and $\mathrm{NH}_{4}{ }^{+}$ as $\left(\mathrm{NH}_{4}\right)_{2} \mathrm{SO}_{4}$. $\mathrm{pH}$ of urea and glycine solutions were 5.6 and 5.2, respectively, while $\mathrm{pH}$ of $\mathrm{NO}_{3}{ }^{-}$and $\mathrm{NH}_{4}{ }^{+}$were 5.3. For each $\mathrm{N}$ form we prepared two solutions. The first solution contained a $\mathrm{N}$ form at natural abundance $\left(0.3664\right.$ atom $\%{ }^{15} \mathrm{~N}$ and 1.082 atom $\left.\%{ }^{13} \mathrm{C}\right)$, while the second solution contained the same $\mathrm{N}$ form but enriched in ${ }^{15} \mathrm{~N}$ (labeled $\mathrm{N}$ form) (60 atom\% for ${ }^{15} \mathrm{NO}_{3}{ }^{-}$and ${ }^{15} \mathrm{NH}_{4}{ }^{+}$and 98 atom\% for urea- ${ }^{15} \mathrm{~N}_{2}$, Sigma Aldrich Co, Milwaukee, USA) or 
${ }_{2-{ }^{13}} \mathrm{C}^{15} \mathrm{~N}$ dual labeled glycine $\left(98-99\right.$ atom $\%{ }^{15} \mathrm{~N}-{ }^{13} \mathrm{C}$ glycine, Cambridge Isotope Laboratories, London, UK). Labeled $\mathrm{NO}_{3}{ }^{-}, \mathrm{NH}_{4}{ }^{+}$and urea were applied individually to each of 10 replicate seedlings per species while the labeled glycine solution was applied to 15 replicate seedlings per species (labeled seedlings). The different $\mathrm{N}$ forms of unlabeled solutions were applied individually to 6 replicate seedlings per species (unlabeled seedlings).

The experiment was run on two dates separated by three days and approximately half of the plants were used on each date.

\subsection{Application method and quantification of the solution retained in shoots.}

The experiment was carried out in the beginning of March 2009. First, pots were sealed with a plastic sheet to avoid substrate contamination during foliar fertilization. Then shoots were sprayed both laterally and from above to ensure complete impregnation of the shoot, three times per day (7:00, 12:00 and 17:00 h solar time) for two days inside a laboratory. Photosynthetic photon flux density was $990 \pm 59,84 \pm 5$, and $44 \pm 6 \mu \mathrm{mol} \mathrm{m}^{-2} \mathrm{~s}^{-1}$ at 7:00, 12:00 and 17:00 h, respectively, while temperature and relative humidity during the experiment were $22.5 \pm 0.5^{\circ} \mathrm{C}$ and $42.9 \pm 1.6 \%$ (mean $\pm 1 \mathrm{SE}$ ), respectively. The solution volume needed to saturate the shoot without dripping was previously determined $(1.01 \pm 0.02 \mathrm{~mL})$. The initial and final weight of the sprayer was recorded to quantify the solution applied to each seedling. To quantify the amount of solution intercepted by the canopy we surrounded shoots with a cone of pre-weighed filter paper. After spraying, the paper was immediately inserted in a plastic bag to prevent humidity loss and weighed again. The volume of solution retained by each plant (retained volume, RV) was calculated as the difference between the total solution sprayed and the solution retained in the filter paper:

$$
\mathrm{RV}=\left[P_{\mathrm{fs}}-P_{\mathrm{is}}\right]-\left[P_{\mathrm{fp}}-P_{\mathrm{ip}}\right] \quad(\mathrm{mL})
$$


where: $P_{\mathrm{fs}}, P_{\mathrm{fp}}$ are final weight of the sprayer and filter paper, respectively; and $P_{\mathrm{is}}, P_{\mathrm{ip}}$ are initial weight of the sprayer and filter paper, respectively. Solution density was $\sim 1 \mathrm{~g} \mathrm{~mL}^{-1}$. Total solution sprayed per plant at the end of the experiment was $6.05 \pm 0.06 \mathrm{~mL}$. There were no significant differences in the volume of sprayed solution between species or among $\mathrm{N}$ forms (Table 1).

\subsection{Processing of plant material and determination of cuticular conductance to water vapor.}

Four plants per species were harvested at the beginning of the experiment (control plants), while another 10-15 replicate labeled and 4 unlabeled plants per species were harvested 12 hours after the last fumigation. Shoots were cut at the point where the plastic was sealed, under the first leaf of the shoot, and roots were frozen until processed. Then the residual transpiration for each shoot was measured following methodology in Villar-Salvador et al. (2004b), whereby shoots were weighed to the nearest $0.1 \mathrm{mg}$ every $20 \mathrm{~min}$ for $8 \mathrm{~h}$. By plotting shoot fresh weight against time a curvilinear relationship was obtained, in which the linear portion is assumed to represent the water loss from plant surfaces after complete stomatal closure. After fresh weight measurement, leaf area was determined with an image analyzer (Delta-T Image Analysis System 1.12, Delta-T Devices LTD, UK) and stem diameter and height were used to determine the stem surface area assuming the stem to be a cone. Area of absorbing surface (AS) was calculated as leaf + stem area. Residual transpiration was calculated as the ratio of the slope of the linear portion of the time-weight plot and AS. Cuticular conductance to water vapor $\left(g_{\mathrm{c}}\right)$ was calculated from measured rates of residual transpiration using an Ohm's Law analogy (Nobel, 1983):

$$
\mathrm{RT}=\delta \mathrm{C}_{\mathrm{v}} \times \mathrm{g}_{\mathrm{c}} \quad\left(\mathrm{mmol} \mathrm{m} \mathrm{s}^{-2} \mathrm{~s}^{-1}\right)
$$


where RT is the residual transpiration, $\delta C_{\mathrm{v}}$ is the mole fraction concentration gradient of water vapor between the leaf and the laboratory atmosphere (based on temperature and relative humidity measurements taken next to seedlings).

In order to remove nutrients retained on plant surfaces, leaves and stems were washed with soapy water and rinsed with tap water (Peuke et al., 1998; Adriaenssens et al., 2010) after measuring residual transpiration. Root plugs were carefully washed from the growing media. Then all plant material was rinsed in de-ionized water twice for 5 minutes. Finally, all organs were oven-dried at $60{ }^{\circ} \mathrm{C}$ for $48 \mathrm{~h}$ and weighed to determine their mass. Plant masses for $Q$. ilex and P. halepensis were 5.0 \pm 0.2 and $2.02 \pm 0.03 \mathrm{~g}$, respectively, while shoot heights were 15.2 \pm 0.4 and $11.9 \pm 0.3 \mathrm{~cm}$, respectively. Neither plant masses nor shoot heights significantly differed among treatments within a species (Table 1).

\subsection{Isotopic analyses and calculation of absorption and allocation to roots}

Roots and shoots were ground separately in a ball mill (PM100, Retsch, Haan, Germany). N and $\mathrm{C}$ concentration and ${ }^{15} \mathrm{~N}$ and ${ }^{13} \mathrm{C}$ abundance were determined by IRMS (CF-IRMS Isochrom, Micromass, UK) at the UC Davis Stable Isotopes Laboratory. Shoot N concentration of control plants in $P$. halepensis and $Q$. ilex were $14.9 \pm 0.3$ and $14.3 \pm 0.2 \mathrm{mg}$, respectively and these values were within the recommended range of $\mathrm{N}$ concentration for 233 nursery seedlings of these species (Villar-salvador et al., 2004; Oliet et al., 2006). The amount of $\mathrm{N}$ absorbed from a labeled $\mathrm{N}$ form $\left(\mathrm{N}_{\text {absorbed }}\right)$ was calculated as:

$$
\mathrm{N}_{\text {absorbed }}=\mathrm{X}_{N} \times\left[\mathrm{N}_{\text {organ }}\right\rfloor \times \mathrm{DM} \quad(\mathrm{mg})
$$

where $\left[\mathrm{N}_{\text {organ }}\right]$ is the organ (shoot or root) $\mathrm{N}$ concentration; $\mathrm{DM}$ is the organ or plant mass, and $X_{\mathrm{N}}$ is the fraction of $\mathrm{N}$ from a labeled $\mathrm{N}$ form in the organ or in the plant (Adriaenssens et al., 2010): 


$$
X_{N}=\frac{\left(A_{L O}\right)-\left(A_{U O}\right)}{\left(A_{L F}\right)-\left(A_{U F}\right)}
$$

where $A_{\mathrm{LO}}$ and $A_{\mathrm{UO}}$ are the ${ }^{15} \mathrm{~N}$ abundance (atom\%) of the organ in labeled and unlabeled samples, respectively. $A_{\mathrm{LF}}$ and $A_{\mathrm{UF}}$ are the ${ }^{15} \mathrm{~N}$ abundance of the labeled and unlabeled fertilizer, respectively. The amount of $\mathrm{C}$ absorbed from the dual labeled ${ }^{15} \mathrm{~N}-{ }^{13} \mathrm{C}$ glycine ( $C_{\text {absorbed }}$ ) was calculated using the same equations but substituting $X_{\mathrm{N}}, N_{\text {organ }}$ or ${ }^{15} \mathrm{~N}$ abundance for $X_{\mathrm{C}}, C_{\text {organ }}$ and ${ }^{13} \mathrm{C}$ abundance, respectively.

$\mathrm{N}$ absorption rate of each $\mathrm{N}$ form was calculated as:

$$
\mathrm{N} \text { absorption rate }=\frac{N_{\text {absorbed }}}{\mathrm{AS} \times \text { time }} \quad\left(\mathrm{mg} \mathrm{m}^{-2} \text { day }^{-1}\right)
$$

$\mathrm{N}$ absorption efficiency $\left(N_{\text {recovery }}\right)$ of each $\mathrm{N}$ form was calculated as:

$$
N_{\text {recovery }}=\frac{N_{\text {absorbed }}}{N_{\text {retained on the shoot }}} \times 100
$$

$\mathrm{N}$ retained on the shoot was calculated as $\mathrm{RV} \times[\mathrm{N}]$ of the solution.

Because glycine can be decomposed by leaf surface microbes, we followed two methods to assess whether glycine was taken up intact. The first method calculates the proportion of glycine absorbed intact by comparing how much the slope of the regression line between $C_{\text {absorbed }}$ against $N_{\text {absorbed }}$ in plant deviates from the regression line of slope $=1254$ predicted from the stoichiometry of intact dual labeled glycine uptake (i.e., 1 mol of ${ }^{13} \mathrm{C}$ per mol of ${ }^{15} \mathrm{~N}$ ) (Näsholm et al., 1998; Warren, 2012). The second method analyzed the amount of $2-{ }^{13} \mathrm{C}^{15} \mathrm{~N}-$ glycine in a sample by gas chromatography-mass spectrometry (GC-MS) of tertbutyldimethylsilyl derivatives. ${ }^{12} \mathrm{C},{ }^{14} \mathrm{~N}$-glycine was quantified from mass, and ${ }^{13} \mathrm{C},{ }^{15} \mathrm{Nglycine}$ 
was quantified from mass 248 after subtracting the contribution to mass from unlabeled samples. For a detailed description of the method see Warren (2012).

\subsection{Statistical analyses}

As the experiment was run on two dates, first we analyzed the effect of dates on all the variables. As dates was not statistically significant in any case it was excluded from subsequent analyses. The effects of $\mathrm{N}$ form and species on $\mathrm{N}$ absorption rate were assessed by 264 analysis of covariance (ANCOVA) with $g_{\mathrm{c}}$ as the covariate. As the parallelism hypothesis was 265 not met, a separates slopes ANCOVA was conducted. Differences between species or among $\mathrm{N}$ forms in the slope of the regressions between $\mathrm{N}$ formform absorption $v s$. cuticular conductance were conducted by checking the significance of regression coefficient $\beta_{3}$ from the model: $\mathrm{N}$ absorption $=\beta_{0}+\beta_{1} \cdot g_{\mathrm{c}}+\beta_{2} \cdot \mathrm{Z}+\beta_{3} \cdot g_{\mathrm{c}} \cdot \mathrm{Z}+\varepsilon$

where $\beta_{\mathrm{i}}$ are the regression coefficients, $\mathrm{Z}$ is a categorical variable representing the species or the $\mathrm{N}$ forms and $\varepsilon$ is the random term of the model (Doménech, 1999). Differences between species in $\mathrm{N}$ absorption rate of intact glycine and $\mathrm{N}$ from glycine after deamination were assessed by one-way ANCOVA with $g_{c}$ as covariate. Species and N form effect on plant mass, height, AS, partitioning of $\mathrm{N}$ absorbed within shoots and roots, $N_{\text {recovery }}$ and organ $\mathrm{N}$ concentration was analyzed by two-ways ANOVA. Differences in shoot and root $\mathrm{N}$ content between the control and each $\mathrm{N}$ form seedlings were analyzed by a one-tailed t-student test. Data homocedasticity was checked according to Levenne's test. When ANOVA assumptions were not met, data was transformed using logarithm, inverse or square root functions.

Significance level was $\alpha=0.05$ for all analyses. Statistical analyses were analyzed with STATISTICA 7.0 (StatSoft, Tulsa, USA).

\section{Results}

\subsection{Foliar $\mathbf{N}$ absorption of different forms and cuticular conductance}


The volume of fertilizer solution retained on the seedling shoot (RV) differed between species, with $Q$. ilex retaining more solution than $P$. halepensis $(3.31 \pm 0.10$ and $2.11 \pm 0.05 \mathrm{~mL}$ for $Q$. ilex and P. halepensis; Table 1). In contrast, RV was independent of $\mathrm{N}$ form applied. AS was $79 \pm 2$ and $77 \pm 3 \mathrm{~cm}^{2}$ for $P$. halepensis and $Q$. ilex, AS did not differ between species and was not affected by $\mathrm{N}$ form or the species $\times \mathrm{N}$ form interaction (Table 1). In both species $\mathrm{RV}$ was positively related to AS $\left(\mathrm{RV}=126.3 \cdot \mathrm{AS}+1.07 ; \mathrm{r}^{2}=0.32 ; \mathrm{F}_{1,56}=25.6 ; \mathrm{P}<0,001\right.$ for $P$. halepensis and $\mathrm{RV}=204.3 \cdot \mathrm{AS}+1.70 ; \mathrm{r}^{2}=0.53 ; \mathrm{F}_{1,58}=19.3 ; \mathrm{P}<0.001$ for $Q$. ilex $)$, but intercepts and slopes of regressions differed between species $\left(\mathrm{F}_{1,96}=5.9 ; \mathrm{P}=0.017\right)$. The intercept of the regression line, which represents the amount of solution retained by aboveground parts other than leaves or main stems, such as short stems or leaf margin, was higher in $Q$. ilex than in P. halepensis. Similarly, RV per AS, as indicated by the slope of the regression line, was $62 \%$ higher in $Q$. ilex than in P. halepensis (204.3 and $126.3 \mathrm{ml} \mathrm{m}^{-2}$, respectively).

Q. ilex had lower $g_{\mathrm{c}}$ than P. halepensis (4.9 $\pm 0.4 v$ s. $13.1 \pm 1.5 \mathrm{mmol} \mathrm{m}^{-2} \mathrm{~s}^{-1}$, respectively). $\mathrm{N}$ absorption rate, calculated on a whole plant level, was strongly positively related to $g_{\mathrm{c}}$ (Table 1). Slopes of the regressions for $Q$. ilex were significantly steeper than slopes for $P$. halepensis (Figure 1). In both species slopes of the linear regressions between plant absorption rate and $g_{\mathrm{c}}$ were not significant for $\mathrm{NO}_{3}{ }^{-}$but were significant and differed among urea, glycine and $\mathrm{NH}_{4}{ }^{+}$ $\left(\mathrm{F}_{3,26}=17.1 ; \mathrm{P}<0.001\right.$ and $\mathrm{F}_{3,27}=21.7 ; \mathrm{P}<0.001$ for $P$. halepensis and $Q$. ilex, respectively). Slopes of the regression lines were steepest for urea and lowest for glycine, whilst slopes for $\mathrm{NH}_{4}{ }^{+}$had intermediate values.

Species and $\mathrm{N}$ form affected absorption rate of $\mathrm{N}$ at the plant level (Table 1, Figure 2a). Quercus ilex had higher $\mathrm{N}$ absorption rate than $P$. halepensis. $\mathrm{N}$ absorption rate differed among $\mathrm{N}$ forms and differences were independent of the species. The rate of $\mathrm{N}$ absorption from urea was approximately three times higher than from the other $\mathrm{N}$ forms. No statistical differences in 
$\mathrm{N}$ absorption rates were found among the remaining $\mathrm{N}$ forms, although the trend was that absorption rate decreased in the following order: $\mathrm{NH}_{4}{ }^{+} \geq$glycine $\geq \mathrm{NO}_{3}{ }^{-}$.

\subsection{Nitrogen absorption efficiency, translocation to roots and organ $\mathrm{N}$ content}

Species and $\mathrm{N}$ form affected the proportion of $\mathrm{N}$ retained on foliage that was absorbed

( $\left.N_{\text {recovery }}\right)$ (Figure $2 \mathrm{~b}$, Table 1$)$. However, the effect of $\mathrm{N}$ form on $N_{\text {recovery }}$ depended on species (Species $\times \mathrm{N}$ form interaction). The $N_{\text {recovery }}$ from urea was significantly higher than for the other $\mathrm{N}$ forms in both species. $\mathrm{NO}_{3}{ }^{-}$had the lowest $N_{\text {recovery }}$ in $Q$. ilex, while $\mathrm{NH}_{4}{ }^{+}$and glycine had similar values yet higher than $\mathrm{NO}_{3}{ }^{-} . N_{\text {recovery }}$ in $P$. halepensis decreased in the following order: $\mathrm{NH}_{4}{ }^{+}>\mathrm{NO}_{3}{ }^{-}>$glycine.

For all $\mathrm{N}$ forms, most of the $\mathrm{N}$ that was recovered was in the shoot (>90\%, Figure $2 \mathrm{c}$ ). Quercus ilex translocated higher $\mathrm{N}$ amounts to roots than $P$. halepensis for all $\mathrm{N}$ forms (data not shown). Nitrogen formform and species affected the proportion of $\mathrm{N}_{\text {absorbed }}$ that was detected in roots, although interaction between both factors also was significant (Table 1). Partitioning of $N_{\text {absorbed }}$ to the roots was smaller in $Q$. ilex than in P. halepensis for all $\mathrm{N}$ forms except for $\mathrm{NO}_{3}{ }^{-}$. Both organic $\mathrm{N}$ forms had lower proportions of $N_{\text {absorbed }}$ that was detected in roots than inorganic $\mathrm{N}$ forms in $Q$. ilex, while this only occurred for urea in $P$. halepensis.

In both species, neither shoot nor root $\mathrm{N}$ content differed between the two dates on which the experiment was performed $\left(\mathrm{F}_{1,81}=0.20 ; \mathrm{P}=0.65\right.$ and $\mathrm{F}_{1,81}=0.02 ; \mathrm{P}=0.90$ for shoot and root $\mathrm{N}$ content, respectively). $\mathrm{N}$ form affected shoot and root $\mathrm{N}$ content (Table 1; Figure

3). Overall, control plants had lower shoot and root $\mathrm{N}$ content than foliar-fertilized seedlings. Shoot and root $\mathrm{N}$ content was higher in seedlings fertilized with urea than in seedlings fertilized with $\mathrm{NO}_{3}{ }^{-}, \mathrm{NH}_{4}{ }^{+}$or glycine. In addition to the significantly higher amounts of urea than other $\mathrm{N}$ forms, there was a non-significant trend for $\mathrm{N}$ content to decrease in the following order: 
$\mathrm{NH}_{4}{ }^{+}>\mathrm{NO}_{3}{ }^{-} \geq$glycine. Increase in $\mathrm{N}$ content of the seedlings after treatment application was ten or more times larger than that derived from foliar absorption itself. Only

$10 \%$ of $\mathrm{N}$ increase in $\mathrm{N} Q$. ilex plants sprayed with urea was explained by foliar uptake and $5 \%$ in the remaining $\mathrm{N}$ forms. In $P$. halepensis $8 \%$ of the increase in $\mathrm{N}$ of urea sprayed plants was explained by foliar uptake while only $3 \%$ of the increment in $\mathrm{N}$ could be attributed to foliar uptake of the other $\mathrm{N}$ forms.

\subsection{Intact glycine absorption estimation}

At the plant level, $C_{\text {absorbed }}$ was strongly linearly related to $N_{\text {absorbed. }}$ The proportion of glycine absorbed as intact molecules was estimated by the slope of the linear regression between plant $C_{\text {absorbed }}$ and $N_{\text {absorbed. }}$ Based on the slope of the regressions, $P$. halepensis took up $98 \%$ of glycine in intact form while $Q$. ilex took up $85 \%$ of glycine in intact form (Figure 4a).

${ }^{15} \mathrm{~N}$ enrichment was detected in shoots and roots of glycine-fertilized seedlings in both species. ${ }^{13} \mathrm{C}$ enrichment was detected in the shoots of both species, but only in the roots of $P$. halepensis (data not shown). $C_{\text {absorbed }}$ was strongly linearly related to $N_{\text {absorbed }}$ at shoot level. $N_{\text {absorbed }}$ taken up from glycine was mainly in shoots. The proportion of intact glycine estimated in shoots was high for both species, as indicated by the slope of $C_{\text {absorbed }} v s . N_{\text {absorbed }}$ (Figure 4b), and was significantly higher in $P$. halepensis $(94 \%)$ than $Q$. ilex (82\%). The estimated amount of glycine absorbed in intact form in shoots was also higher in $P$. halepensis than in $Q$. ilex $\left(\mathrm{F}_{1,29}=10.7 ; \mathrm{P}<0.001\right.$; Figure $\left.4 \mathrm{c}\right)$. Pinus halepensis roots were both

${ }^{15} \mathrm{~N}$ and ${ }^{13} \mathrm{C}$ enriched but there was no significant relationship between $C_{\text {absorbed }}$ and $N_{\text {absorbed }}$ (data not shown) and $C_{\text {absorbed }}$ was lower than $N_{\text {absorbed }}$ with the $C_{\text {absorbed }} / N_{\text {absorbed }}$ ratio being 0.22. The mean ${ }^{13} \mathrm{C}$ abundance in $Q$. ilex roots was similar to that in control plants, and no $C_{\text {absorbed }}$ was found in roots in most seedlings (data not shown). The uptake rate of intact dual labeled glycine detected by GC-MS in shoots was $5.8 \%$ of total glycine uptake in P. halepensis 
and $10 \%$ of total glycine uptake in $Q$. ilex $\left(\mathrm{F}_{1,25}=19.7 ; \mathrm{P}<0.001\right.$; Figure $\left.4 \mathrm{c}\right) . g_{\mathrm{c}}$ was a significant covariate for intact dual labeled glycine detected by GC-MS $\left(\mathrm{F}_{1,25}=6.3 ; \mathrm{P}=0.02\right)$.

\section{Discussion}

\subsection{Differences in foliar absorption between species}

Both species were able to absorb $\mathrm{N}$ from $\mathrm{NO}_{3}{ }^{-}, \mathrm{NH}_{4}{ }^{+}$, urea and glycine via their shoots. We did not assess the contribution of leaves and stems to shoot $\mathrm{N}$ absorption. However, we suggest that absorption through stems may be lower than through leaves both because they represent a low proportion of shoot surface (10 and $7 \%$ for $Q$. ilex and $P$. halepensis, respectively) and usually have lower uptake capacity than leaves (Schaefer and Reiners, 1990).

In accordance with our hypothesis, $\mathrm{N}$ absorption was higher in $Q$. ilex than in $P$. halepensis suggesting that atmospheric $\mathrm{N}$ deposition and foliar fertilization in the nursery will potentially have greater impact on nutrition of $Q$. ilex than on $P$. halepensis. Similar to our findings, three broadleaf trees had rates of $\mathrm{NH}_{4}{ }^{+}$and $\mathrm{NO}_{3}{ }^{-}$foliar $\mathrm{N}$ uptake that were two to six times higher than the conifer Pinus sylvestris L. (Adriaenssens et al., 2010). Differences in uptake rate between species can be attributed to several factors. First, $Q$. ilex leaves had higher liquid retention than $P$. halepensis needles in spite of having similar AS. This indicates that $Q$. ilex is intrinsically capable of intercepting and/or retaining more liquid on its shoots than $P$. halepensis. This is probably due to the possession of broad leaves that are inserted at a steep angle on the shoot and the presence of trichomes in $Q$. ilex. In agreement with our findings, $P$. sylvestris also showed lower RV than three deciduous broadleaf trees (Adriaenssens et al., 2010). Second, as foliar absorption is a concentration gradient driven process (Brumme et al., 1992; Peuke et al., 1998; Bi and Scagel, 2008) and shoot N concentration was slightly higher in $P$. halepensis than in $Q$. ilex, the potential for $\mathrm{N}$ diffusion (i.e. concentration gradient) would 
have been lower in $P$. halepensis than in $Q$. ilex. Third, $\mathrm{N}$ absorption can occur through stomata, and species differ in their ability to take up compounds through stomata (Eichert and Goldbach, 2008). Positive relationships between foliar nutrient absorption and the number and distribution of stomata have been observed in several species (Eichert and Goldbach, 2008). On this basis, we expected stomatal penetration of $\mathrm{N}$ compounds to be more difficult in $P$. halepensis than in Q. ilex because $P$. halepensis has lower stomatal density (32 to 39 stomata $\mathrm{mm}^{-2}$; Mohammad Suleiman, 1986) than Q. ilex (253 to 391 stomata $\mathrm{mm}^{-2}$; Uzunova et al., 1997; Paoletti et al., 1998; Calatayud et al., 2011). Furthermore, while stomata of $Q$. ilex are located at the leaf surface (Bussotti and Grossoni, 1997), stomata of $P$. halepensis are inside epistomatic chambers which frequently are partially sealed with a wax plug (Mohammad Suleiman, 1986). Finally, the abaxial face of $Q$. ilex leaves is covered by a dense layer of fused-stellate trichomes (Bussotti and Grossoni, 1997). The base and branches of trichomes have been identified as penetration sites for solutes (Benzing et al., 1976; Schreiber, 2005) and residence time of solution in contact with the cuticle is increased by trichomes (Karabourniotis et al., 1998).

The greater $\mathrm{N}$ absorption in $Q$. ilex relative to $P$. halepensis cannot be explained by higher cuticle water permeability in the former species. On the contrary, the shoot surface of $Q$. ilex was less permeable to water (as indicated by lower $g_{\mathrm{c}}$ ) than $P$. halepensis (Figure 1 ), which supports the importance of other factors in determining shoot $\mathrm{N}$ absorption such as interception capacity, stomatal properties or presence of trichomes. However, this result does not invalidate the importance of the cuticle pathway for $\mathrm{N}$ absorption. Changes in cuticular permeability to water at an intraspecific level clearly influence $\mathrm{N}$ absorption in both species, as indicated by the strong relationship between $g_{\mathrm{c}}$ and $\mathrm{N}$ absorption for all $\mathrm{N}$ forms except for $\mathrm{NO}_{3}{ }^{-}$. Interestingly, the slope of the relationship between absorption rate and $g_{\mathrm{c}}$ differed between species, suggesting that the factors underpinning permeability to $\mathrm{N}$ differ between 
species. A partial explanation may lie in the fact that composition and structure of cuticle waxes differ between species (Mohammad Suleiman, 1986; Panahi et al., 2012), and differences in cuticle absorption are sometimes more closely related to the composition and structure of the cuticle waxes than to wax content or cuticle thickness (Santier and Chamel, 1998; Bondada et al., 2006; Adriaenssens et al., 2010). In contrast to the smooth cuticle of Q. ilex (Bussotti and Grossoni, 1997), P. halepensis has a cluster tubular wax cuticle structure (Boddi et al., 2002), which may reduce $\mathrm{N}$ absorption due to lower solution contact with the leaf surface (Adriaenssens et al., 2010).

\subsection{Differences in foliar $\mathbf{N}$ absorption among $\mathbf{N}$ forms}

The relative differences in $\mathrm{N}$ absorption rate among $\mathrm{N}$ forms were the same in the two species: Urea $\gg \mathrm{NH}_{4}{ }^{+} \geq$glycine $\geq \mathrm{NO}_{3}{ }^{-}$. Other studies also have found faster $\mathrm{N}$ absorption from urea than from other $\mathrm{N}$ forms (usually two to four times faster $\mathrm{N}$ absorption, Eberhardt and Pritchett, 1971; Stiegler et al., 2009). Faster $\mathrm{N}$ absorption from $\mathrm{NH}_{4}{ }^{+}$than $\mathrm{NO}_{3}{ }^{-}$is consistent with other studies (Eberhardt and Pritchett, 1971; Brumme et al., 1992; Peuke et al., 1998; Stiegler et al., 2009). However, $\mathrm{N}$ from urea is not always taken up faster than $\mathrm{N}$ from $\mathrm{NH}_{4}{ }^{+}$. For instance, the epiphytic tank bromeliad Vriesea gigantea (Gaudich.) took up $\mathrm{N}$ from $\mathrm{NH}_{4}{ }^{+}$faster than $\mathrm{N}$ from urea, $\mathrm{NO}_{3}{ }^{-}$or several amino acids (Inselsbacher et al., 2007). We cannot exclude the possibility that transformations among $\mathrm{N}$ forms occurred in our experiment, such as urea to $\mathrm{NH}_{4}{ }^{+}$, or $\mathrm{NH}_{4}{ }^{+}$to $\mathrm{NO}_{3}{ }^{-}$(the deamination of glycine is discussed below), which might have led to slight underestimation or overestimation of $\mathrm{N}$ absorption rate from different chemical forms. However, we believe that transformations were small as suggested by the large difference in $\mathrm{N}$ absorption rates between urea and $\mathrm{NH}_{4}{ }^{+}$(see Figure 2) and the different response of $\mathrm{NH}_{4}{ }^{+}$and $\mathrm{NO}_{3}{ }^{-} \mathrm{N}$ uptake to changes in $g_{\mathrm{c}}$ in both species (Figure $1)$. 
$N_{\text {recovery }}$ of urea was the highest (25\%) while the remaining $\mathrm{N}$ forms had $N_{\text {recovery values }}$ between 8 and 3\%. The capacity of both species to acquire organic $\mathrm{N}$ from urea and glycine and the high $N_{\text {recovery }}$ of urea suggest that the organic $\mathrm{N}$ fraction should also be considered in $\mathrm{N}$ deposition studies. $N_{\text {recovery }}$ in this experiment were lower than values reported in other studies, but the ranking of $\mathrm{N}$ forms was similar to previous findings. Klein and Weinbaum (1985) found

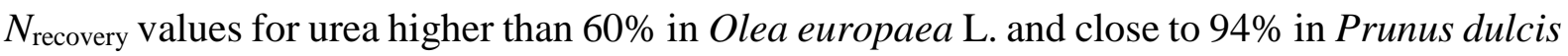
(Mill.) D.A.Webb. Eberhardt and Pritchett (1971) found $N_{\text {recovery }}$ values of $71 \%, 45 \%$ and $39 \%$ for urea, $\mathrm{NO}_{3}{ }^{-}$, and $\mathrm{NH}_{4}{ }^{+}$, respectively in Pinus elliottii. Lower $N_{\text {recovery values in our study can }}$ be attributed to inherent lower leaf permeability to water in $Q$. ilex and P. halepensis (Larcher, 1995), because we did not use surfactants that are known to increase foliar $\mathrm{N}$ absorption (Coker et al., 1987), the nutrient status of the plants-prior to fertilization (Dong et al., 2002), the duration of the experiment, the concentration of $\mathrm{N}$ forms or the method used for determining $N_{\text {recovery. }}$ In this respect it is worth noting that several of the highest published $N_{\text {recovery }}$ values were estimated as the difference between the amount of sprayed $\mathrm{N}$ and the amount of $\mathrm{N}$ washed from leaf surfaces after absorption, but with this method $N_{\text {recovery }}$ can be overestimated because of $\mathrm{N}$ that is volatilized (Al-Kanani et al., 1991).

Differences among $\mathrm{N}$ forms in absorption rates may be related to their penetration mechanisms and physicochemical properties. While ionic compounds can only use polar aqueous pores to penetrate cuticle, non-ionic molecules, such as organic $\mathrm{N}$ compounds, can penetrate the cuticle via both the lipophilic pathway and polar aqueous pores (Riederer and Schreiber, 2001; Eichert and Goldbach, 2008). This probably explains the high $\mathrm{N}$ uptake rates from urea. Although glycine is also a non-ionic compound, its $\mathrm{N}$ uptake rate was lower than from urea and can be explained by its higher molecular weight and other physicochemical properties (that are discussed below) (Santier and Chamel, 1998). Moreover, since leaf surfaces 
are partially permeable to water, compounds that are highly soluble in water penetrate more easily through polar aqueous pores than less soluble compounds (Riederer and Schreiber, 2001). Thus, urea, the compound with fastest $\mathrm{N}$ uptake rates, has the highest solubility (108 $\mathrm{g}$ $100 \mathrm{ml}^{-1}$ at $\left.20^{\circ} \mathrm{C}\right)$ and lowest hygroscopicity $(10 \%$ deliquescence point at 25

${ }^{\circ} \mathrm{C}$ ), which allows deposits to lengthen the aqueous phase for an extended period of time (Bondada et al., 2006). By contrast, $\mathrm{NO}_{3}{ }^{-}$, the $\mathrm{N}$ form with slowest absorption, has the lowest solubility and highest hygroscopicity (38 g $100 \mathrm{ml}^{-1}$ and 94\%, respectively). Finally, $\mathrm{NH}_{4}{ }^{+}$and

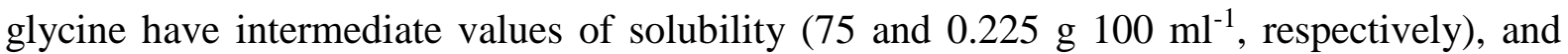
hygroscopicity (46 and 94\%, respectively) and had also intermediate $\mathrm{N}$ uptake rates between urea and $\mathrm{NO}_{3}{ }^{-}$.

Rates of foliar uptake of $\mathrm{N}$ forms were differentially affected by permeability of the cuticle to water ( $g_{\mathrm{c}}$, Figure 1), with urea having a steeper slope of $\mathrm{N}$ absorption rate $v s . g_{\mathrm{c}}$ than the other $\mathrm{N}$ forms. These differences probably also reflect distinct penetration mechanisms of the different $\mathrm{N}$ compounds. Notably, the lack of a significant relationship between $\mathrm{NO}_{3}{ }^{-}-\mathrm{N}$ absorption and $g_{c}$ in both species suggests that limitations imposed on anion permeability through the cuticle are unaffected by differences in cuticle water permeability and that leaf penetration of $\mathrm{N}^{-\mathrm{NO}_{3}}{ }^{-}$probably is more linked to stomata than to the cuticular pathway, as shown in other studies (Eichert and Burkhardt, 2001; Eichert and Goldbach, 2008). Finally, the independence of $\mathrm{N}^{-\mathrm{NO}_{3}}{ }^{-}$absorption and $g_{\mathrm{c}}$ suggests that faster $\mathrm{N}$ absorption in plants with higher $g_{c}$ is unlikely due to incomplete stomatal closure.

Plants can benefit from foliar fertilization with amino acids, due to lower cost of metabolism to proteins than inorganic $\mathrm{N}$ forms, but this benefit applies only if amino acids are taken up intact. Our study demonstrates that only part of the glycine retained on shoot surface was taken up intact. However, the methodologies used to assess intact glycine uptake, ${ }^{13} \mathrm{C}-{ }^{15} \mathrm{~N}$ 
molar ratios and GC-MS, have some limitations due to pre- and post-uptake metabolism. According to the ${ }^{13} \mathrm{C}-{ }^{15} \mathrm{~N}$ molar ratio method, $85 \%$ and $65 \%$ of glycine was taken up intact in P. halepensis and Q. ilex, respectively (Figure 3a), reducing accordingly the $N_{\text {recovery }}$ of glycine. As we quantified ${ }^{15} \mathrm{~N}$ and ${ }^{13} \mathrm{C}$ at plant level, underestimation of intact glycine due to transfer of ${ }^{15} \mathrm{~N}$ and/or ${ }^{13} \mathrm{C}$ to other molecules inside the plant (Warren, 2012) cannot be supported. However, a ${ }^{13} \mathrm{C}-{ }^{15} \mathrm{~N}$ molar ratio similar to the reference stoichiometry of intact dual-labeled glycine could also be achieved if glycine were mineralized on the leaf surface and ${ }^{13} \mathrm{C}$ and ${ }^{15} \mathrm{~N}$ were subsequently taken up independently (Warren, 2012). Similarly, ${ }^{13} \mathrm{CO}_{2}$ respiration loss after glycine metabolism can also alter organ ${ }^{13} \mathrm{C}-{ }^{15} \mathrm{~N}$ molar ratio (Warren, 2012). Thus, results obtained from the ${ }^{13} \mathrm{C}-{ }^{15} \mathrm{~N}$ molar ratio method must be interpreted with caution and considered as an estimation of potential amount of glycine taken up intact. On the contrary, the GC-MS method measures the exact amount of intact glycine inside the plant. The amount of intact glycine detected by this method was low in both species and notably lower than intact glycine estimated by the ${ }^{13} \mathrm{C}-{ }^{15} \mathrm{~N}$ molar ratio method. Glycine is quickly metabolized (Warren, 2012) and our experiment lasted 2 days, which might explain why only a small proportion of intact glycine was detected inside the plant (i.e. a large proportion may have been taken up intact, but most was metabolized to other compounds within 2 days). Both methods of quantifying intact glycine showed that $Q$. ilex had lower intact glycine absorption than $P$. halepensis. It is possible that a proportion of glycine was decomposed before absorption by microbial community in the phyllosphere, which usually is C-limited and tends to immobilize C-rich forms on the leaf surface (Mercier and Lindow, 2000). Presence of a dense trichome layer in $Q$. ilex leaves might promote phyllosphere microbe growth (Mercier and Lindow, 2000) and consequently a faster rate of glycine deamination.

\section{3. $\mathbf{N}$ loading and translocation as a function of $\mathbf{N}$ form}


Foliar $\mathrm{N}$ fertilization, especially with urea, increased the shoot and root $\mathrm{N}$ content up to $21 \%$ in P. halepensis and $18 \%$ in Q. ilex (Figure 3) after a very short period, two days. Similar to our findings, foliar fertilization has been shown to increase plant $\mathrm{N}$ content during autumn (Dong et al., 2002; Bi and Scagel, 2008). Additionally, despite the high concentration used (40 $\mathrm{mM} \mathrm{N}$ ), none of the $\mathrm{N}$ forms caused foliar necrosis or other adverse responses, indicating that the two species are tolerant to high $\mathrm{N}$ concentrations and salinity on leaves. This high tolerance to salinity on leaves suggest that $\mathrm{N}$ deposition even at high $\mathrm{N}$ inputs will have negligible negative effects in these species.

Our results indicate that foliar fertilization could complement conventional tree nursery fertilization regimes that are based on root $\mathrm{N}$ uptake. Foliar fertilization would be especially advantageous when root $\mathrm{N}$ uptake is hindered by low soil temperature (Romanya et al., 2001; Warren, 2009), when seedlings have high nutrient demand such as in spring (Montville, 1996; Fernández and Eichert, 2009) or high amounts of $\mathrm{N}$ are leached from the growing medium ,due to irrigation (Lamhamedi et al., 2001) and heavy rainfall in the autumn, Similarly, foliar fertilization could improve plant nutrition in seedlings outplanted in nutrientpoor soils or arid conditions (Ruiz Navarro, 2012) where $\mathrm{N}$ root uptake can also be limited by high microbial competition (Bardgett et al., 2003; Delgado-Baquerizo and Gallardo, 2011) and drought (Ruiz Navarro, 2012).

The increment in $\mathrm{N}$ content was consistent with differences in absorption rate among $\mathrm{N}$ forms. However, we note that less than $10 \%$ of the increase in $\mathrm{N}$ content was directly attributed to foliar uptake. As plant $\mathrm{N}$ content did not change between the two dates in which the experiment was performed our results suggest that the remainder of the increase in $\mathrm{N}$ content was due to root uptake. This suggests that foliar fertilization might have indirectly stimulated $\mathrm{N}$ uptake by roots, a process which also has been observed in Malus domestica Borkh (Dong 
et al., 2002), in several carnivorous plants (Adamec, 2002), and in Stipa tenacissima and Rosmarinus officinalis under arid conditions (Ruiz Navarro, 2012). Future studies should analyze the relationship between $\mathrm{N}$ foliar fertilization and $\mathrm{N}$ uptake by roots.

Despite the short duration of the experiment, both species rapidly translocated some $\mathrm{N}$ from shoots to the roots as indicated by the presence of labeled $\mathrm{N}$ from all $\mathrm{N}$ forms in the roots. Pinus halepensis proportionally translocated more N (4\%) than Q. ilex (3\%), but these values are smaller than the $15 \%$ reported for Lolium perenne L. (Bowman and Paul, 1992) or $10 \%$ for Olea europaea L. (Klein and Weinbaum, 1985) two days after fertilizer application. Differences in partitioning among species can be attributed to different relative sink strength of the organs. Distribution of foliar-applied $\mathrm{N}$ is known to change with time of application (Dong et al., 2002). Our experiment was carried out during spring when sink strength of shoots is usually higher than roots (Millard and Grelet, 2010); thus we expect higher translocation to roots when shoot but not root growth is arrested, such as occurs in the fall (Klein and Weinbaum, 1985; Dong et al., 2002). The greater $\mathrm{N}$ translocation in all $\mathrm{N}$ forms and greater $\mathrm{C}$ translocation in glycine fertilized-seedlings in $P$. halepensis than in $Q$. ilex may be due to differences in metabolism of $\mathrm{N}$ forms or to a different root demand between species ( $\mathrm{Bi}$ and Scagel, 2008; Warren, 2012). High $\mathrm{NO}_{3}{ }^{-}$translocation in both species could be explained by lower assimilation capacity in leaves than in roots (Rennenberg and Gessler, 1999). This is supported by measurements showing the concentration of nitrate reductase in both species is lower in leaves than in roots $\left(8 \pm 2\right.$ and $825 \pm 70 \mu \mathrm{mol} \mathrm{NO} 2 \mathrm{~g}$ fresh weight $(\mathrm{FW})^{1}$ in leaves and roots respectively in $P$. halepensis and $28 \pm 3$ and $146 \pm 12 \mu \mathrm{mol} \mathrm{NO} \mathrm{g} \mathrm{FW}^{-1}$ in $Q$. ilex; Uscola unpublished data). Conversion of urea into amino acids mainly occurs in leaves (Calanni et al., 1999), which might explain the proportionally lower $\mathrm{N}$ root translocation from urea relative to the other $\mathrm{N}$ forms in both species. Finally, glycine metabolism seems to differ between $Q$. ilex 
and $P$. halepensis. Results suggest that glycine is completely metabolized in $Q$. ilex shoots as neither intact glycine nor ${ }^{13} \mathrm{C}$ enrichment was detected in $Q$. ilex roots, while ${ }^{13} \mathrm{C}$ enrichment was found in P. halepensis roots.

\section{Conclusions}

This study demonstrates that two Mediterranean trees are able to absorb all of the studied forms of $\mathrm{N}$ through their leaves. Foliar $\mathrm{N}$ absorption was higher in $Q$. ilex than in $P$. halepensis and differed among $\mathrm{N}$ forms, following the pattern urea $>\mathrm{NH}_{4}{ }^{+} \geq$glycine $\geq \mathrm{NO}_{3}{ }^{-}$for both species. Both species absorbed a proportion of glycine intact, with a larger proportion of glycine taken up intact in $P$. halepensis than in $Q$. ilex. Cuticle permeability did not explain interspecific differences in absorption rate, but within-species, absorption of $\mathrm{N}$ from all chemical forms was positively related to cuticle permeability except $\mathrm{NO}_{3}{ }^{-}$. A small proportion of the $\mathrm{N}$ absorbed by shoots was rapidly translocated to roots. Shoot fertilization increased organ $\mathrm{N}$ content, but only a part of this increase could be attributed to direct shoot $\mathrm{N}$ uptake with the remainder probably reflecting an increase in root uptake in foliar-fertilized plants. This study demonstrates that two important Mediterranean forest tree species can absorb through their leaves $\mathrm{N}$ forms that are present in natural $\mathrm{N}$ deposition. Moreover, differences in rates of absorption between species and among $\mathrm{N}$ forms mean that the effect of $\mathrm{N}$ deposition will vary between plant species and depend upon the mixture of $\mathrm{N}$ forms that comprise $\mathrm{N}$ deposition. We show that $\mathrm{N}$ leaf fertilization, especially with urea, can be a tool to complement conventional fertilization regimes based on root $\mathrm{N}$ uptake, for both nursery cultivation and potentially nutrient improvement of seedlings outplanted in nutrient-poor soils or arid conditions.

\section{Acknowledgements}

We are grateful to Centro Nacional de Recursos Genéticos Forestales "El Serranillo" (MAGRAMA) for cultivating us the plants. We also grateful Karla B. Quispe Clemente for her 
help at the laboratory. This study was supported by a FPU-MEC grant to M. Uscola, and by projects AGL2006-12609-C02-01/FOR (ENCINUT), AGL2011-24296 ECOLPIN

(MICIIN), and the network REMEDINAL 2 (S2009/AMB/1783) of the Community of

Madrid. Charles Warren is supported by a Future Fellowship from the Australian Research Council.

\section{References}

Adamec L. 2002. Leaf absorption of mineral nutrients in carnivorous plants stimulates root nutrient uptake. New Phytol 155: 89-100.

Adriaenssens S, Staelens J, Wuyts K, Schrijver A, Wittenberghe S, Wuytack T, Kardel F, Verheyen K, Samson R, Boeckx P. 2010. Foliar nitrogen uptake from wet deposition and the relation with leaf wettability and water storage capacity. Water Air Soil Poll. 219: 4357.

Al-Kanani T, MacKenzie AF, Barhakur NN. 1991. Soil water and ammonia volatilization relationships with surface-applied nitrogen fertilizer solutions. Soil Sci Soc Am J 55: $1761-1766$.

Baquedano FJ, Castillo FJ. 2006. Comparative ecophysiological effects of drought on seedling of the Mediterranean water-saver Pinus halepensis and water-spenders Quercus coccifera and Quercus ilex. Trees 20: 689-700.

Bardgett RD, Streeter TC, Bol R. 2003. Soil microbes compete effectively with plants for organic-nitrogen inputs to temperate grasslands. Ecology 84: 1277-1287.

Baur P, Buchholz A, Schönherr J. 1997. Diffusion in plant cuticles as affected by temperature and size of organic solutes: similarity and diversity among species. Plant Cell Env. 20: 982-994. 
Benzing DH, Henderson K, Kessel B, Sulak J. 1976. The absorptive capacities of bromeliad trichomes. Am. J. Bot. 63: 1009-1014.

Bi G, Scagel CF. 2008. Nitrogen uptake and mobilization by Hydrangea leaves from foliarsprayed urea in fall depend on plant nitrogen status. Hortic. Sci. 43: 2151-2154.

Boddi S, Bonzi LM, Calamassi R. 2002. Structure and ultrastructure of Pinus halepensis primary needles. Flora 197: 10-23.

Bondada BR, Petracek PD, Syvertsen JP, Albrigo LG. 2006. Cuticular penetration characteristics of urea in citrus leaves. J. Hort. Sci. Biotech. 81: 219-224.

Bowman DC, Paul JL. 1992. Foliar absorption of urea, ammonium, and nitrate by perennial ryegrass turf. Am. J. Soc. Hort. Sci. 117: 75-79.

Brumme R, Leimcke U, Matzner E. 1992. Interception and uptake of $\mathrm{NH}_{4}{ }^{+}$and $\mathrm{NO}_{3}{ }^{-}$from wet deposition by above-ground parts of young beech (Fagus silvatica L.) trees. Plant Soil 142: $273-279$.

Burghardt M, Riederer M. 2003. Ecophysiological relevance of cuticular transpiration of deciduous and evergreen plants in relation to stomatal closure and leaf water potential. J. Exp. Bot. 54: 1941-1949.

Burkhardt J. 2010. Hygroscopic particles on leaves: nutrients or desiccants? Ecol. Monogr. 80: 369-399.

Bussotti F, Grossoni P. 1997. European and Mediterranean oaks (Quercus L.; Fagaceae): SEM characterization of the micromorphology of the abaxial leaf surface. Bot. J. Linn. Soc. 124: 183-199.

Bytnerowicz A, Fenn ME. 1996. Nitrogen deposition in California forests: a review. Environ. Pollut. 92: 127-46. 
Calanni J, Berg E, Wood M, Mangis D, Boyce R, Weathers W, Sievering H. 1999. Atmospheric nitrogen deposition at a conifer forest: response of free amino acids in Engelmann spruce needles. Env. Poll. 105: 79-89.

Calatayud V, Cerveró J, Calvo E, García-Breijo FJ, Reig-Armiñana J, Sanz MJ. 2011. Responses of evergreen and deciduous Quercus species to enhanced ozone levels. Env. Pollut. 159: 55-63.

Coker A, Court D, Silvester WD. 1987. Evaluation of foliar urea applications in the presence and absence of surfactant on the nitrogen requirements of conditioned Pinus radiata seedlings. New Zeal. J. For. Sci. 17: 51-66.

Cornell SE. 2011. Atmospheric nitrogen deposition: revisiting the question of the importance of the organic component. Env. Poll. 159: 2214-2222.

Delgado-Baquerizo M, Gallardo A. 2011. Depolymerization and mineralization rates at 12 Mediterranean sites with varying soil $\mathrm{N}$ availability. A test for the Schimel and Bennett model. Soil Biol. Biochem. 43: 693-696.

Doménech JM. 1999. Análisis multivariante en ciencias de la salud: modelos de regresión.

Universitat Autònoma de Barcelona. Laboratori d'Estadídtica Aplicada i de Modelització. Ed. Signo, Barcelona.

Dong S, Cheng L, Scagel CF, Fuchigami LH. 2002. Nitrogen absorption, translocation and distribution from urea applied in autumn to leaves of young potted apple (Malus domestica) trees. Tree Physiol. 22: 1305-1310.

Eberhardt PJ, Pritchett WL. 1971. Foliar applications of nitrogen to slash pine seedlings. Plant Soil 34: 731-740.

Eichert T, Burkhardt J. 2001. Quantification of stomatal uptake of ionic solutes using a new model system. J. Exp. Bot. 52: 771-781. 
Eichert T, Goldbach HE. 2008. Equivalent pore radii of hydrophilic foliar uptake routes in stomatous and astomatous leaf surfaces-further evidence for a stomatal pathway. Physiol. Plant. 132: 491-502.

Eichert T, Kurtz A, Steiner U, Goldbach HE. 2008. Size exclusion limits and lateral heterogeneity of the stomatal foliar uptake pathway for aqueous solutes and watersuspended nanoparticles. Physiol. Planta. 134: 151-60.

Fageria NK, Barbosa Filho MP, Moreira A, Guimaraes CM. 2009. Foliar fertilization of crop plants. J. Plant Nutr. 32: 1044-1064.

Fagerli H, Aas W. 2008. Trends of nitrogen in air and precipitation: model results and observations at EMEP sites in Europe, 1980--2003. Environ. Pollut. 154: 448-61.

Fernández V, Eichert T. 2009. Uptake of hydrophilic solutes through plant leaves: current state of knowledge and perspectives of foliar fertilization. Crit Rev Plant Sci. 28: 36-68.

Fernández V, Sotiropoulos TE, Brown P. 2013. Foliar fertilization: scientific principles and field practices. Pp 142.

Inselsbacher E, Cambui CA, Richter A, Stange CF, Mercier H, Wanek W. 2007. Microbial activities and foliar uptake of nitrogen in the epiphytic bromeliad Vriesea gigantea. New Phytol. 175: 311-320.

Karabourniotis G, Kofidis G, Fasseas C, Liakoura V, Drossopoulos I. 1998. Polyphenol deposition in leaf hairs of Olea europaea (Oleaceae) and Quercus ilex (Fagaceae). Am. J. Bot. 85: 1007-1012.

Klein I, Weinbaum SA. 1985. Foliar application of urea to almond and olive: leaf retention and kinetics of uptake. J. Plant Nutr. 8: 117-129.

Lamhamedi M, Lambany G, Margolis H, Renaud M, Veilleux L, Bernier PY. 2001. Growth, physiology and leachate losses in Picea glauca seedlings (1+0) grown in air-slit containers under different irrigations regimes. Can. J. For. Res. 31: 1968-1980. 
Larcher W. 1995. Physiological Plant Ecology. Springer pp. 506

LeBauer DS, Treseder KK. 2008. Nitrogen limitation of net primary productivity in terrestrial ecosystems is globally distributed. Ecology 89: 371-379.

Maini P. 2006. The experience of the first biostimulant, based on amino acids and peptides: a short retrospective review on the laboratory researches and the practical results. Fertil. Agrorum 1: 29-43.

Mercier J, Lindow SE. 2000. Role of leaf surface sugars in colonization of plants by bacterial epiphytes. Appl. Environ. Microb. 66: 369-374.

Michopoulos P, Baloutsos G, Economou A, Nikolis N. 2004. Effects of nitrogen deposition on nitrogen cycling in an Aleppo pine stand in Athens, Greece. Water 323: 211-218.

Millard P, Grelet G-A. 2010. Nitrogen storage and remobilization by trees: ecophysiological relevance in a changing world. Tree Physiol. 30: 1083-1095.

Mohammad Suleiman A. 1986. Morpho-physiological evaluations of Aleppo and Brutia pine seedlings under two different moisture regimes. School of renewable natural reforms. University of Arizona. Pp 116.

Montville ME. 1996. Foliar fertilization during bud initiation improves container-grown ponderosa pine seedling viability. West. J. Appl. For. 11: 114-119.

Näsholm T, Ekblad A, Nordin A, Giesler R, Högberg MN, Högberg P. 1998. Boreal forest plants take up organic nitrogen. Nature 392: 914-916.

Niederl S, Kirsch T, Riederer M, Schreiber L. 1998. Co-permeability of ${ }^{3} \mathrm{H}-$ labeled water and ${ }^{14} \mathrm{C}$-labeled organic acids across isolated plant cuticles: Investigating cuticular paths of diffusion and predicting cuticular transpiration. Plant Physiol. Bioch. 116: 117-123.

Nobel PS. 1983. Biophysical plant physiology and ecology. WH Freeman, San Francisco. 
Ochoa-Hueso R, Allen EB, Branquinho C, Cruz C, Dias T, Fenn ME, Manrique E, PérezCorona ME, Sheppard LJ, Stock WD. 2011. Nitrogen deposition effects on Mediterranean-type ecosystems: an ecological assessment. Env. Poll. 159: 2265-2279.

Oliet JA, Valdecantos A, Puértolas J, Trubat. R. 2006. Influencia del estado nutricional y el contenido en carbohidratos en el establecimiento de las plantaciones. In J Cortina, JL Peñuelas, J Puértolas, R Savé, A.Vilagrosa., eds, Calidad de planta Forestal para la restauración en Ambientes mediterráneos. Estado actual de conococimiento. pp 89-117. OAPN-MMA (España).

Panahi P, Jamzad Z, Pourmajidian MR, Fallah A, Pourhashemi M. 2012. Foliar epidermis morphology in Quercus (subgenus Quercus, section Quercus) in Iran. Acta Bot. Croatica 71: $95-113$.

Paoletti E, Nourrisson G, Garrec JP, Raschi A. 1998. Modifications of the leaf surface structures of Quercus ilex L. in open, naturally $\mathrm{CO}_{2}$-enriched environments. Plant Cell Env. 21: 1071-1075.

Peuke AD, Jeschke WD, Dietz K-J, Schreiber L, Hartung W. 1998. Foliar application of nitrate or ammonium as sole nitrogen supply in Ricinus communis I. Carbon and nitrogen uptake and inflows. New Phytol. 138: 675-687.

Raison RJ, Stottlemyer R. 1991. Considerations in modeling change in temperate forest nitrogen cycles. Tree Physiol. 9: 209-225.

Rennenberg H, Gessler A. 1999. Consequences of $\mathrm{N}$ deposition to forest ecosystems- recent results and future research needs. Water Air Soil Poll. 116: 47-64.

Riederer M, Schreiber L. 2001. Protecting against water loss: analysis of the barrier properties of plant cuticles. J. Exp. Bot. 52: 2023-2032.

Roda F, Avila A, Rodrigo A. 2002. Nitrogen deposition in Mediterranean forests. Environ 
Pollut. 118: 205-213.

Romanya J, Casals P, Vallejo VR. 2001. Short-term effects of fire on soil nitrogen availability in Mediterranean grasslands and shrublands growing in old fields. For. Ecol. Manage. 147: $39-53$

Ruiz Navarro A. 2012. Fertilidad edáfica en un ecosistema semiárido mediterráneo: relaciones con la estructura de la vegetación y el comportamiento funcional de las especies dominantes. PhD Dissertation. Departamento de Química Agrícola, Geología y Edafología. Universidad de Murcia, CSIC, pp 275.

Santier S, Chamel A. 1998. Reassessment of the role of cuticular waxes in the transfer of organic molecules through plant cuticles. Plant Physiol. Bioch. 36: 225-231.

Sanz MJ, Carratalá A, Gimeno C, Millán. MM. 2002. Atmospheric nitrogen deposition on the east coast of Spain: relevance of dry deposition in semi-arid Mediterranean regions. Env. Poll. 118: 259-272.

Schaefer DA, Reiners WA. 1990. Trough fall chemistry and canopy processing mechanisms. In SE Linderberg, AL Page, SA Norton, eds, Acidic precipitation, vol 3. Forms, deposition and canopy interactions. Springer-Verlag, Berlin, pp 241-278.

Schreiber L. 2005. Polar paths of diffusion across plant cuticles: new evidence for an old hypothesis. Ann. Bot. 95: 1069-1073.

Stiegler C, Richardson M, Mccalla J. 2009. Foliar uptake of inorganic and organic nitrogen compounds by creeping Bentgrass putting green turf. Arkansas Turfgrass Report 2008, Ark. Ag. Exp. Stn Re. Ser. 568: 116-120.

Uzunova K, Palamarev E, Ehrendorfer F. 1997. Anatomical changes and evolutionary trends in the foliar epidermis of extant and fossil Euro-Mediterranean oaks (Fagaceae). Pl Syst Evol 204: 141-159. 
Vicente-Serrano SM. 2006. Differences in Spatial Patterns of Drought on Different Time Scales: An Analysis of the Iberian Peninsula. Water Resour. Manag. 20: 37-60.

Villar-Salvador P, Planelles R, Enríquez E, Peñuelas Rubira J. 2004a. Nursery cultivation regimes, plant functional attributes, and field performance relationships in the Mediterranean oak. For. Ecol. Manage. 196: 257-266.

Villar-Salvador P, Planelles R, Oliet J, Penuelas-Rubira JL, Jacobs DF, González M. 2004b. Drought tolerance and transplanting performance of holm oak (Quercus ilex) seedlings after drought hardening in the nursery. Tree Physiol. 24: 1147-1155.

Villar-Salvador P, Puértolas J, Cuesta B, Peñuelas JL, Uscola M, Heredia-Guerrero N, Rey Benayas JM. 2012. Increase in size and nitrogen concentration enhances seedling survival in Mediterranean plantations: Insights from an ecophysiological conceptual model of plant survival. New For. 43: 755-770.

Warren CR. 2009. Why does temperature affect relative uptake rates of nitrate, ammonium and glycine: A test with Eucalyptus pauciflora. Soil Biol. Bioch. 41: 778-784.

Warren CR. 2012. Post-uptake metabolism affects quantification of amino acid uptake. New Phytol. 193: 522-531.

Zavala MA, Espelta JM, Retana J. 2000. Constraints and trade-offs in Mediterranean plant communities: the case of holm oak-Aleppo pine forests. Bot. Rev. 66: 119-149.

Zohlen A, Tyler G. 2000. Immobilization of tissue iron on calcareous soil: differences between calcicole and calcifuge plants. Oikos 89: 95-106. 


\section{Figure captions}

Figure 1. Linear regressions between the $\mathrm{N}$ absorption rate of different $\mathrm{N}$ forms calculated on a whole plant basis and cuticular conductance $\left(g_{c}\right)$ in Quercus ilex and Pinus halepensis one year-old seedlings. Subfigures are for urea (a), $\mathrm{NH}_{4}{ }^{+}$(b), glycine (c) and $\mathrm{NO}_{3}{ }^{-}$(d). Seedlings were sprayed three times a day for two days with $40 \mathrm{mM} \mathrm{N}$ solutions. Each point represents an individual.

Figure 2. $\mathrm{N}$ Absorption rate on a whole plant basis (a), $\mathrm{N}$ absorption efficiency $\left(N_{\text {recovery }}\right)(\mathrm{b})$ and percentage of total $N_{\text {absorbed }}$ recovered in shoots and roots (c) in urea, glycine, $\mathrm{NH}_{4}{ }^{+}$and $\mathrm{NO}_{3}{ }^{-}$foliar fertilized Quercus ilex and Pinus halepensis one year-old seedlings. Plants were sprayed three times a day for two days. Concentration of sprayed solutions was $40 \mathrm{mM}$ N. Data are means $\pm 1 \mathrm{SE}$, except for foliar $\mathrm{N}$ absorption rate which results are adjusted least squares means computed at $g_{\mathrm{c}}=8.89 \mathrm{mmol} \mathrm{m}^{-2} \mathrm{~s}^{-1}$.

Figure 3. N content in shoots and roots of Quercus ilex (a) and Pinus halepensis (b) one yearold seedlings that were sprayed three times a day for two days with $40 \mathrm{mM} \mathrm{N}$ solutions of urea, $\mathrm{NH}_{4}{ }^{+}$, glycine and $\mathrm{NO}_{3}{ }^{-} . \mathrm{N}$ concentration of plants immediately before foliar fertilization (control) is given. Data are means \pm 1 SE. For each $\mathrm{N}$ form asterisks indicate statistically significant differences with controls after one tailed t-student tests: $* 0.01<\mathrm{P} \leq 0.05$; ** $0.001<\mathrm{P} \leq 0.01 ; * * * \mathrm{P} \leq 0.001, \mathrm{~ns}: \mathrm{P}>0.05$

Figure 4. Regressions between $C_{\text {absorbed }}$ and $N_{\text {absorbed }}$ at plant (a) and shoot (b) level in glycine foliar-fertilized Quercus ilex and Pinus halepensis one year-old seedlings that were sprayed three times a day for 2 days with $40 \mathrm{mM} \mathrm{N}$ solutions. Each point represents an individual. Solid 
thick line is the expected reference line with slope 1 according to ${ }^{13} \mathrm{C}$ and ${ }^{15} \mathrm{~N}$ stoichiometry in intact dual labeled glycine. Subfigure (c) is total (intact + de-aminated glycine as $\mathrm{NH}_{4}{ }^{+}$form) and $\mathrm{N}$ absorption rate from intact glycine estimated by regression analysis in shoots and roots, and dual labeled glycine detected by GC-MS in shoots in both species (note the different scales of $\mathrm{Y}$-axes for shoots and roots in subfigure c). Least square means $\pm 1 \mathrm{SE}$ in shoots were computed for $g_{\mathrm{c}}=8.89 \mathrm{mmol} \mathrm{m} \mathrm{m}^{-2} \mathrm{~s}^{-1} . \mathrm{N}_{\text {absorbed }}$ was standardized by plant part mass instead of absorbing surface, in order to make possible comparisons between shoots and roots.

Table 1. Two-way ANOVA results (F and p values) for $\mathrm{N}$ forms (Urea, $\mathrm{NH}_{4}{ }^{+}$, glycine and $\mathrm{NO}_{3}{ }^{-}$) and species (Quercus ilex and Pinus halepensis) for different variables of seedlings that were sprayed three times a day for two days with $40 \mathrm{mM} \mathrm{N}$ solutions.

\begin{tabular}{|c|c|c|c|c|}
\hline & Species (1) & $\mathrm{N}$ form (2) & $1 \times 2$ & Covariable $\left(\mathrm{g}_{\mathrm{c}}\right)$ \\
\hline $\begin{array}{l}\text { Volume of sprayed } \\
\text { solution }\end{array}$ & $\begin{array}{c}\mathrm{F}_{1,106}=2.1 \\
\mathrm{P}=0.15\end{array}$ & $\begin{array}{c}\mathrm{F}_{3,106}=0.89 \\
\mathrm{P}=0.44\end{array}$ & $\begin{array}{c}F_{3,106}=0.45 \\
P=0.72\end{array}$ & \\
\hline Plant mass & $\begin{array}{c}F_{1,106}=299 \\
P<0.001\end{array}$ & $\begin{array}{l}\mathrm{F}_{3,106}=0.91 \\
\quad \mathrm{P}=0.43\end{array}$ & $\begin{array}{c}\mathrm{F}_{3,106}=1.3 \\
\mathrm{P}=0.28\end{array}$ & \\
\hline Shoot height & $\begin{array}{c}\mathbf{F}_{1,106}=31 \\
\mathbf{P}<0.001\end{array}$ & $\begin{array}{l}F_{3,106}=0.18 \\
\quad P=0.92\end{array}$ & $\begin{array}{l}F_{3,106}=0.20 \\
\quad P=0.90\end{array}$ & \\
\hline $\begin{array}{l}\text { Retained volume on } \\
\text { plant shoot }(\mathrm{RV})\end{array}$ & $\begin{array}{c}F_{1,106}=138 \\
P<0.001\end{array}$ & $\begin{array}{c}\mathrm{F}_{3,106}=1.1 \\
\mathrm{P}=0.35\end{array}$ & $\begin{array}{c}F_{3,106}=0.77 \\
P=0.51\end{array}$ & \\
\hline Shoot area (AS) & $\begin{array}{c}\mathrm{F}_{1,106}=0.52 \\
\mathrm{P}=0.52\end{array}$ & $\begin{array}{c}\mathrm{F}_{3,106}=0.031 \\
\mathrm{p}=0.81\end{array}$ & $\begin{array}{c}\mathrm{F}_{3,106}=0.02 \\
\mathrm{P}=0.99\end{array}$ & \\
\hline $\mathrm{N}$ absorption rate & $\begin{array}{l}F_{1,74=8.0} \\
P=0.007\end{array}$ & $\begin{array}{l}\text { F3,74=7.5 } \\
\text { P<0.001 }\end{array}$ & $\begin{array}{c}\mathrm{F}_{3,74}=2.1 \\
\mathrm{P}=0.11\end{array}$ & $\begin{array}{l}\text { F8,74=5.5; } \\
P<0.001\end{array}$ \\
\hline$N_{\text {recovery }}$ & $\begin{array}{c}F_{1,53}=9.5 \\
P=0.003\end{array}$ & $\begin{array}{c}F_{3,53}=133 ; \\
P<0.001\end{array}$ & $\begin{array}{c}F_{3,53}=4.9 \\
P=0.004\end{array}$ & \\
\hline $\mathrm{N}_{\text {absorbed }}$ in roots & $\begin{array}{c}F_{1,45}=10.5 \\
P=0.002\end{array}$ & $\begin{array}{l}\text { F3,45 }_{3} \mathbf{4 7} \\
\mathbf{P}<0.001\end{array}$ & $\begin{array}{c}F_{3,45}=13.1 \\
P<0.001\end{array}$ & \\
\hline Shoot N content & $\begin{array}{l}\mathbf{F} 4,83=5.3 \\
P<0.001\end{array}$ & $\begin{array}{c}\mathbf{F}_{1,83}=10.9 \\
\mathbf{P}<0.001\end{array}$ & $\begin{array}{c}\mathrm{F}_{4,83}=1.6 \\
\mathrm{P}=0.20\end{array}$ & \\
\hline Root $\mathrm{N}$ content & $\begin{array}{c}F_{4,83}=4.1 \\
P<0.01\end{array}$ & $\begin{array}{c}F_{1,83}=44.2 \\
P<0.001\end{array}$ & $\begin{array}{c}\mathrm{F}_{4,83}=0.70 \\
\mathrm{P}=0.59\end{array}$ & \\
\hline
\end{tabular}



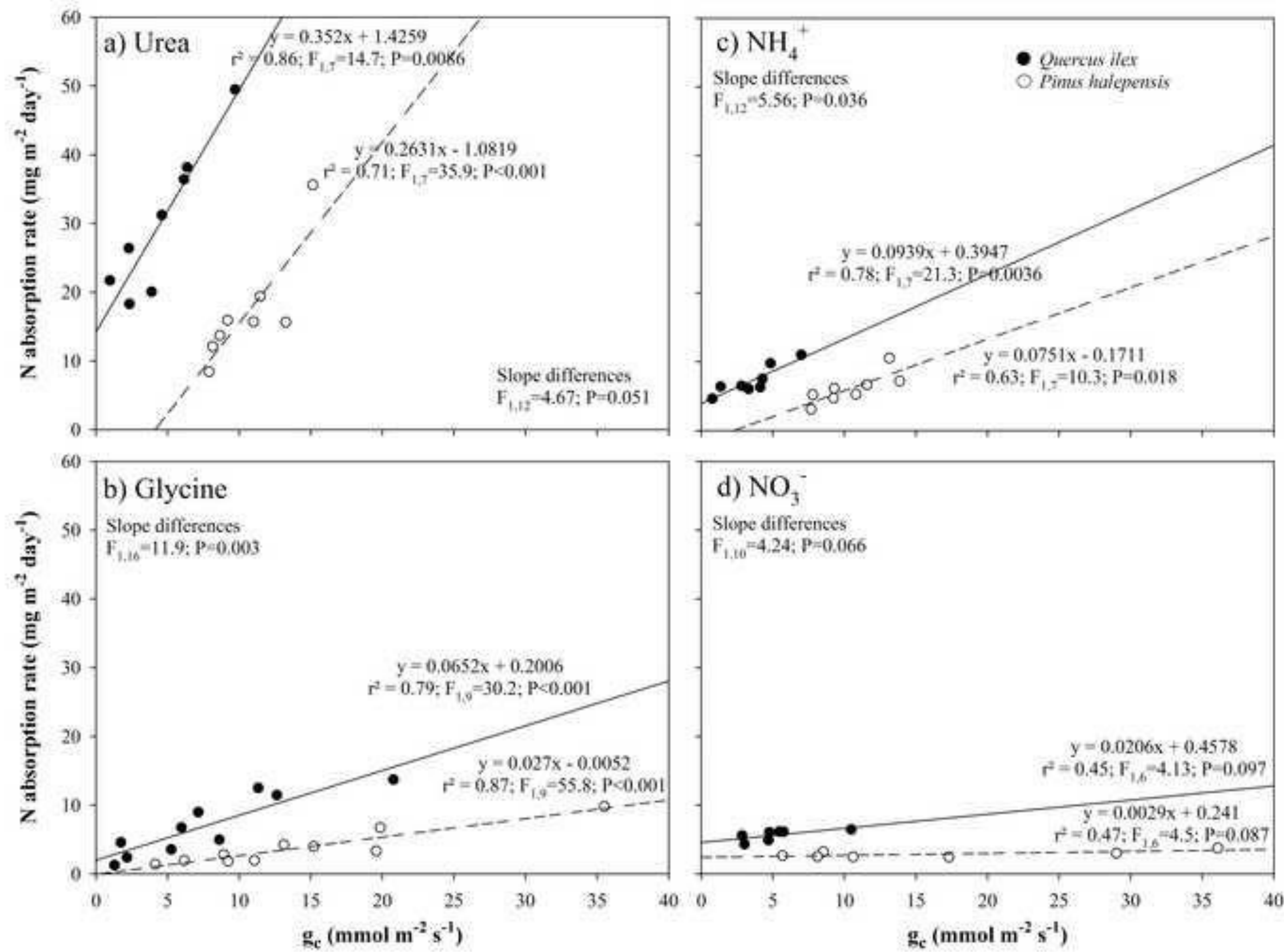

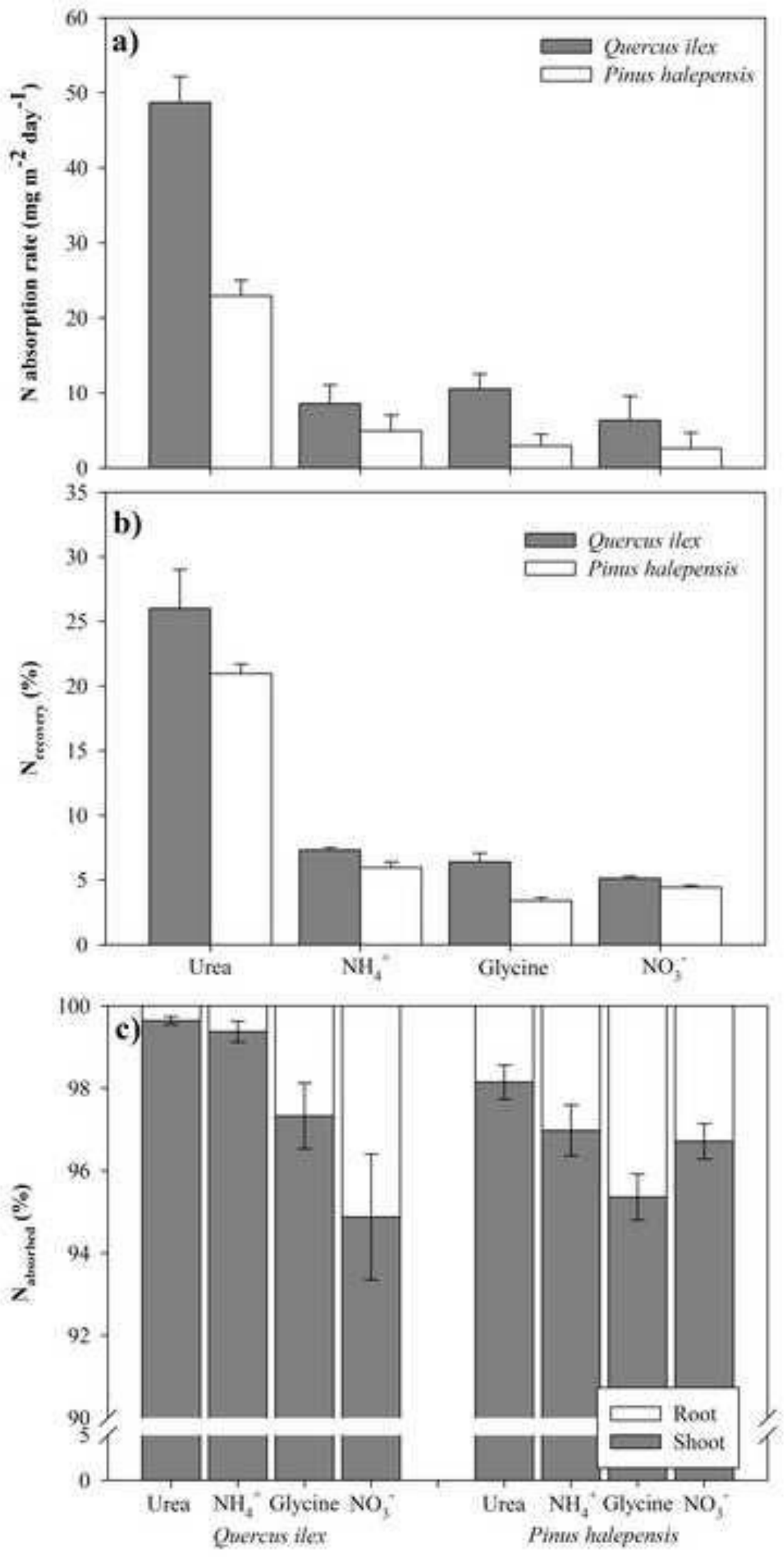

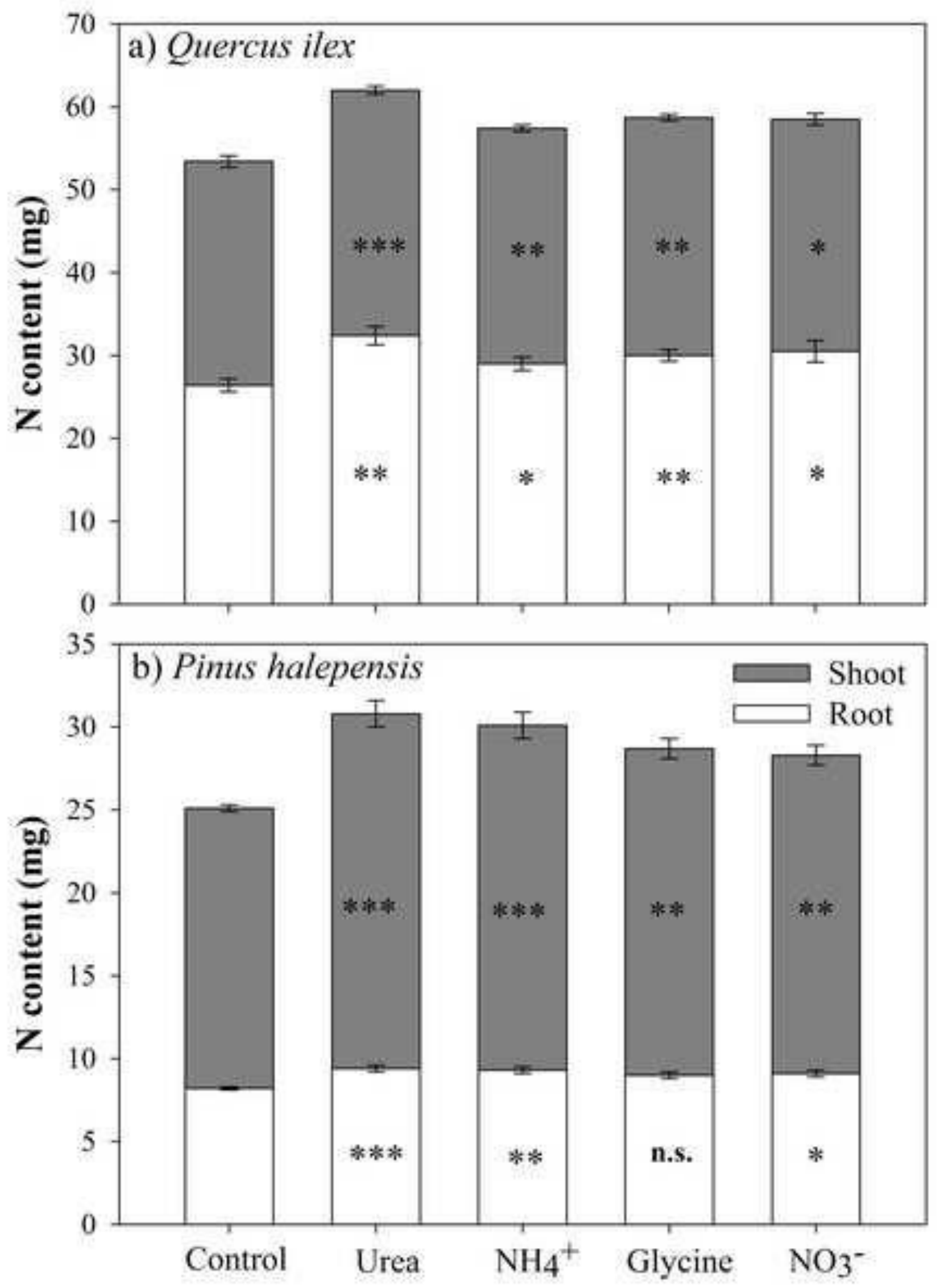


\section{Figure}

Click here to download high resolution image
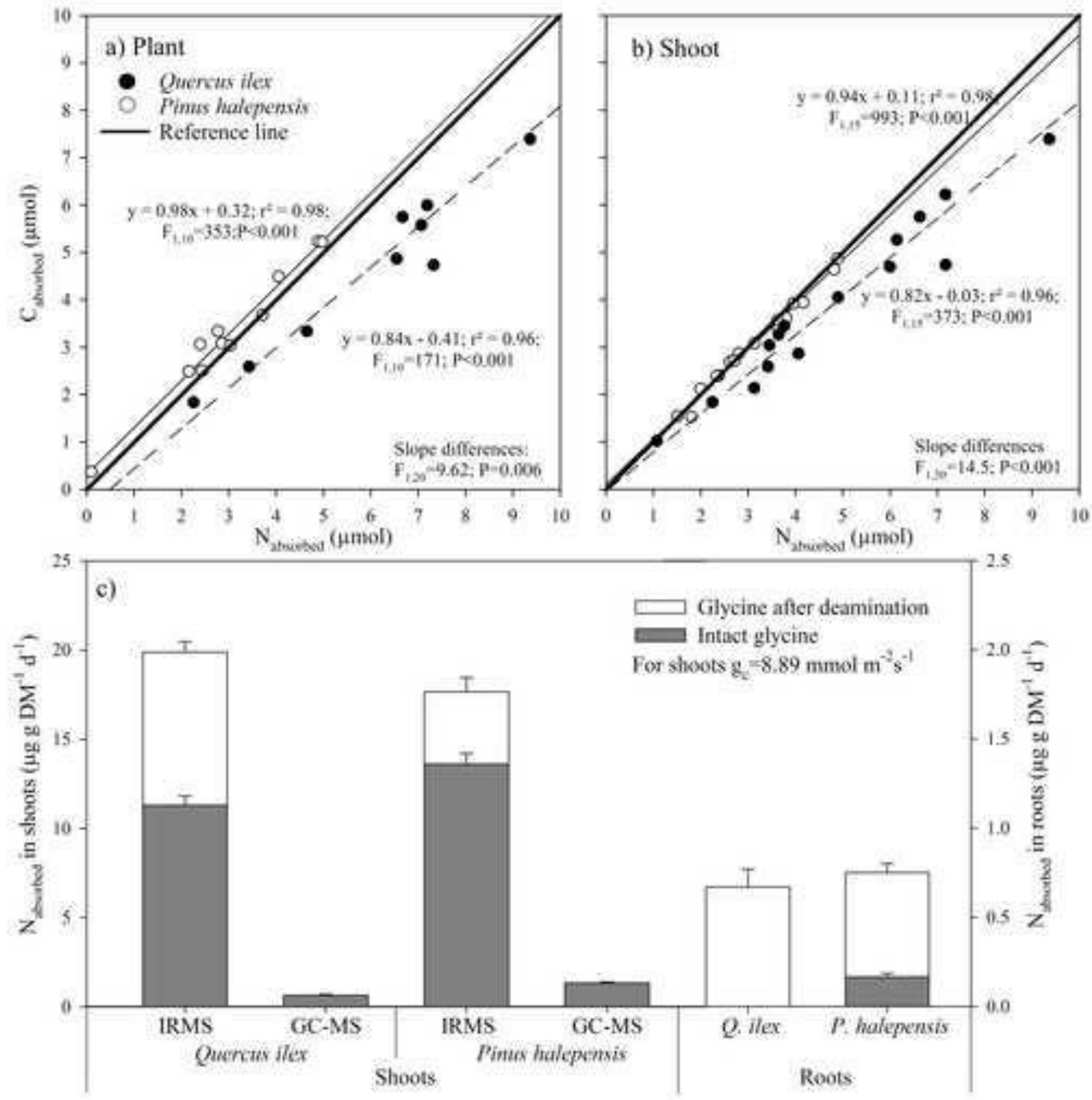